\title{
Assessment and modelling of residual chlorine in water supply systems: The case of Dangila Town, Ethiopia
}

\author{
Wondwesen Tesfaye Semagn ${ }^{1}$, Teka Girmay Hishe ${ }^{2 *}$, Eusman Ebrahim Shumey ${ }^{2}$, Mariye Majo Shute ${ }^{3}$, Atikilt Abebe Ketema ${ }^{4}$ \\ ${ }^{1}$ Master of Water Supply and Sanitary Engineering, Water Resource Development Office, Merhabate Woreda, Ethiopia \\ ${ }^{2}$ Master of Hydraulic Engineering, Faculty of Technology, Debre Tabor University, Debre Tabor, Ethiopia \\ ${ }^{3}$ Master of Chemical Engineering, Faculty of Technology, Debre Tabor University, Debre Tabor, Ethiopia \\ ${ }^{4}$ Assist. Prof., Faculty of Civil and Water Resources Engineering, Bahir Dar University, Bahir Dar, Ethiopia \\ tesfayewesen@gmail.com, tekagirmay@gmail.com, ousebrahim2006@gmail.com, mariye496@gmail.com, \\ atikiltabebe@gmail.com
}

\begin{abstract}
Application of chlorine for drinking water security in the water supply distribution network for the Dangila town is not well managed. The study was conducted by the help of Water CAD software to evaluate the chlorine dosing and residual chlorine model. The necessary data were taken from primary and secondary sources. Three scenarios were developed for modelling the residual chlorine content in the distribution system. Two scenarios were produced with chlorine dose of $0.6 \mathrm{mg} / \mathrm{l}$ at a flow rate of $26 \mathrm{ml} / \mathrm{s}$ and chlorine dose of $0.5 \mathrm{mg} / 1$ at a flow rate of $22 \mathrm{ml} / \mathrm{s}$, respectively. Residual chlorine concentration above normal limits $(0.5 \mathrm{mg} / \mathrm{l})$ was recorded in both scenarios around the injection point whereas four sample points were below $0.2 \mathrm{mg} / \mathrm{l}$. Scenario II, all residual chlorine values were lower than $0.5 \mathrm{mg} / \mathrm{l}$ but still lower than $0.2 \mathrm{mg} / \mathrm{l}$ at the farthest four sampling points. In order to solve the above problem, A third scenario was developed with three reservoir injection points, Junction 4 and 55" within $0.45,0.15$ and $0.2 \mathrm{mg} / \mathrm{l}$ of chlorine in order to maintain appropriate residual chlorine concentration. Hence, the best solution identified from the analysis was the installation of two additional chlorine injection points.
\end{abstract}

KEYWORDS: Residual chlorine, water quality, water cad, injection points, scenario, distribution system

\section{INTRODUCTION}

A human can survive for weeks without food, but it only a few days without water. According to Clark, 2012 Water should contain no chemical or biological contaminants (Bruins, 2000; Clark et al., 1995; Males et al., 1988). Each year millions of people die from diarrhoea caused by contaminated drinking water, especially children. Due to water-related, diseases include waterborne infections such as cholera, typhoid, hepatitis-infection and schistosomiasis. Disinfection is an essential step towards ensuring that water is safe to drink by adding chlorine (Niazi et al., 2017). It is common to add disinfectants in the water supply system to destroy microorganisms that can cause disease in humans (Zaki et al., 2012). Even though there are several methods of disinfection in the world, developing countries like Ethiopia use chlorine to disinfect the water they use. Chlorine is the most common disinfectant used to inactivate waterborne pathogens in drinking water supply and has usually served the most significant contribution to consumer protection and public health (Post, Atherholt, 2011; Soyupak et al., 2011; Yee et al., 2006).

Wei et al. (2010) suggested that chlorination is dramatically reducing the occurrence of waterborne diseases. Nevertheless, chlorine can also combine with natural raw water materials to form by-products of disinfection (DBPs) that are harmful to health in long-term exposure to by-products of disinfection, and increased risk of cancer and possible adverse reproductive effects (Clark et al., 1995).

The residual chlorine in water distribution can be affected by different factors like Temperature, $\mathrm{pH}$ and turbidity. Temperature is one of the water's essential parameters, and it is essential for its impact on the chemistry, and biological reactions on the organisms in the water can lead to a reduction in the amount of residual chlorine, and that can enhance microorganism development. When the amount of $\mathrm{pH}$ in the distribution system is less than 7, it creates corrosion in the distribution system that can cause more chorine bi-products, and the chlorine is less effective if the $\mathrm{pH}$ of water exceeds 8.0 (Ustad, 2018). The other consideration is high turbidity levels that can shield microorganisms from the effects of disinfection, generating a significant demand for chlorine and the efficiency of disinfection (Sorlini et al., 2013). On the other hand, the value of $\mathrm{pH}$ affects 
treatment processes, coagulation and disinfection with chlorine-based chemicals (Hu et al., 2010).

According to Myer and Shaw, 2006 and Bolton and Cotton, 2011, water to be chlorinated it should have a turbidity value $\leq 5$ NTU (Bolton \& Cotton, 2011; Myre \& Shaw, 2006). Chlorination is even more effective when less than one NTU. The other vital chemical water quality parameters that can affect chlorine demand are Calcium, Magnesium, Chlorides, Nitrates and Nitrites (Temgoua, 2011).

It is also imperative to study the amount of residual chlorine in the water distribution system to solve water-related problems. Water cad is one of significant software's that is used to model Pressure, velocity, head loss, water age (Kabir et al., 2015) and residual chlorine (Goyal \& Patel, 2015) in the water distribution system (Mekonnen, 2015).

\section{MATERIALS AND METHODS}

\subsection{Description of study area}

Location of Dangila is in Awi Zone Amhara Regional State. This town has latitude and longitude Coordinates: $11^{\circ} 16^{\prime} \mathrm{N} \quad 36^{\circ} 50^{\prime} \mathrm{E}$ with an average elevation of 2125 meters above sea level. It is far from Addis Ababa, about 485-kilo meters, and from Bahir Dar $78 \mathrm{~km}$ towards the road of Addis Ababa. The central statistical agency in 2013, the town had an estimated total population 26,704 and 34,629 in 2017.

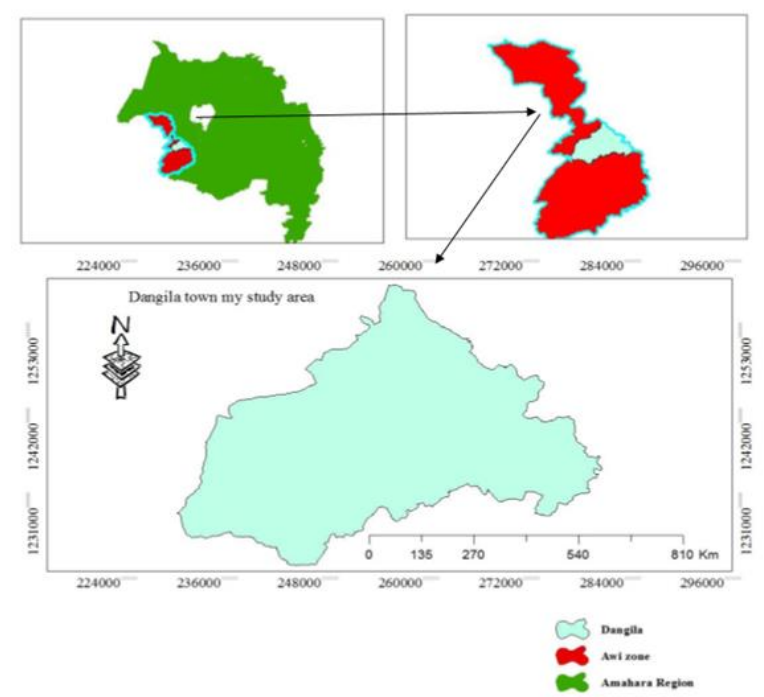

Fig. 1. Topographical location of the study area

The application of chlorine in the distribution system for the safety of drinking water is not well managed for the Dangila town water supply system.
As most of the Ethiopian towns, Dangila town has unbalanced chlorine adding and can affect human in the chronic cause and sometime actuating effects. The source of the water supply system of Dangila town is from four wells from those the three are functional, and the other one is not functional. The system of chlorine application is manually on reservoirs that can result in fluctuations on chlorine amount.

\subsection{Sampling Sites}

One of the essential steps in developing and using water quality monitoring in the network is the collection of water quality sampling points. Usually, the water quality is determined by physical, chemical and biological parameters. These are therefore appropriate for specified water sample points, but it is not economical to measure all of them, so the selected samples depend on the Ethiopian water quality standard agency, 2013. According to ESA, 2013 sampling for bacteriological examination and other water quality parameters should be regular, and its frequency and sizes would mainly depend on the different type of factors (Ododo). These are quality of the water harnessed, type of treatment for drinking worthiness, risks of contamination, background of public water supply network and the number of people served.

The minimum sample size for drinking water in the distribution Population served Sample was taken based on the population. Based on Ethiopia Water Quality Standards Agency, 2013 for the population, which is less than 5,000, one sample, for 5,000100,000 one sample per 5,000 populations and Above 100,000 one sample per 10,000 populations plus 10 sample additional.

\subsection{Sampling and Laboratory analysis}

After fixing the number of sampling sites, the next step was collecting water samples to examined different Physico-chemical and biological parameters that have an adverse impact on chlorine demand. Based on this in addition to secondary date's, primary data's were collected from the selected eight sampling points labelling as SP1, SP2, SP3, SP4, SP5, SP6, SP7 and SP8. The parameters selected to examined the effect of the water quality parameters on residual chlorine concentration were Temperature, $\mathrm{pH}$, turbidity and total coliforms. The evaluation and modelling of the amount of residual chlorine in the distribution system were carried out by the help of water cad software. 


\section{RESULTS AND DISCUSSION}

\subsection{Water quality-related data and their effect on chlorine demand}

Except for $\mathrm{pH}$, the critical chemical water quality parameters that analyses such as $\mathrm{CaCO}_{3}, \mathrm{Mg}, \mathrm{F}, \mathrm{NO}_{3}$, $\mathrm{NO}_{2}, \mathrm{Mn}, \mathrm{Fe}$ and Chloride were found within WHO \& ESA limits that have no significant adverse impact on the residual chlorine. Assessment of Existing Microbial and Residual Chlorine.

Dangila`s town water quality analysis as the Water, Energy and Irrigation Guideline office 2017 reported that the town WSDS have shown not detected with coliforms. Nevertheless, in this study, those reports were not exact. Bacteriological to be safe in drinking water supply system, faecal and total coliforms must be null at any $100 \mathrm{ml}$ drinking water samples (Berhanu \& Hailu, 2015). During the study period, it was found that the disinfection with $1.5 \mathrm{~kg}$ chlorine dose solution by $3 \mathrm{ml} / \mathrm{s}$ flow rates were not full disinfect all the distribution systems. The existing maximum residual chlorine concentration at sample point six through the distribution system by $1.5 \mathrm{~kg} / \mathrm{m}^{3}$ chlorine dose with $3 \mathrm{ml} / \mathrm{s}$ flow rates was found to be $0.17 \mathrm{mg} / \mathrm{l}$ which was less than the minimum recommended by WHO and ESA standard of 0.2 $\mathrm{mg} / \mathrm{l}$ (Fig.2.)

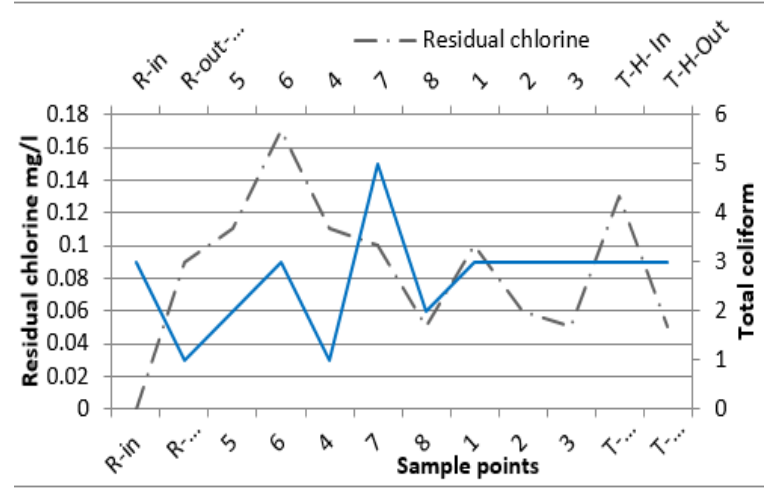

Fig. 2. Current town residual chlorine versus total coliforms

From the total residual chlorine analysis samples that were taken at consumer taps, $50 \%$ of result has recorded above $0.1 \mathrm{mg} / \mathrm{l}$ (including it), but less than $0.2 \mathrm{mg} / \mathrm{l}$ and the other $50 \%$ have resulted below 0.09 $\mathrm{mg} / \mathrm{l}$.

The residual chlorine was analysed after 30minute chlorine demands (Yee et al., 2006). A chlorine dose solution form in mixing tank with the amount of $1.5 \mathrm{~kg}$ was calculated.

From the $1.5 \mathrm{~kg}\left(\mathrm{Ca}(\mathrm{OCl})_{2}\right.$, net chlorine was calculated as 1500 gram x $65 \%$ :

$$
\text { Dose concentration }=\frac{1500 \times 65 \%}{1000 \mathrm{l}}=975 \mathrm{mg} / \mathrm{l}
$$

Initial chlorine dose drops from separated chlorine mixing tank with $2 \mathrm{ml} / \mathrm{s}, 5 \mathrm{ml} / \mathrm{s}$ and $7 \mathrm{ml} / \mathrm{s}$ chlorine solution rates into the well discharge proportion amounts. $2 \mathrm{ml} / \mathrm{s}$ : chlorine dose flow rates, $975 \mathrm{mg} / \mathrm{l}$ chlorine dose in mixing tank. For this study, the value of initial chlorine concentration when, the three out of four wells were worked at the same time $(56 \mathrm{l} / \mathrm{s})$ with $7 \mathrm{ml} / \mathrm{s}$ dose flow rates. The calculated initial chlorine concentration value was $0.12 \mathrm{mg} / \mathrm{l}$. This initial chlorine concentration was not enough to get the minimum residual chlorine throughout the distribution system. Although, for other wells operates in different time by $7 \mathrm{ml} / \mathrm{s}$ chlorine dose flow rates the amount of initial chlorine concentration proportion with well discharge the residual chlorine recorded within the recommended ranges (0.2-0.5 $\mathrm{mg} / \mathrm{l})$.

\subsection{Assessment of disinfection process with $1.5 \mathrm{~kg}$ Chlorine}

The existing of free residual chlorine values were examined in distribution systems as pervious explained all results were recorded less than the minimum recommended values of $0.2 \mathrm{mg} / \mathrm{l}$. To meet the minimum residual chlorine were throughout the distribution system adjusts the chlorine solution flow rates with different amounts of chlorine dose. So, using $1.5 \mathrm{~kg}(\mathrm{Ca}(\mathrm{OCl}) 2$ dose solution $(975 \mathrm{mg} / \mathrm{l})$ within adjusted solution the flow rate into $2 \mathrm{ml} / \mathrm{s} ; 5$ $\mathrm{ml} / \mathrm{s}$ and $7 \mathrm{ml} / \mathrm{s}$ were assessing residual chlorine (Fig. $3)$.

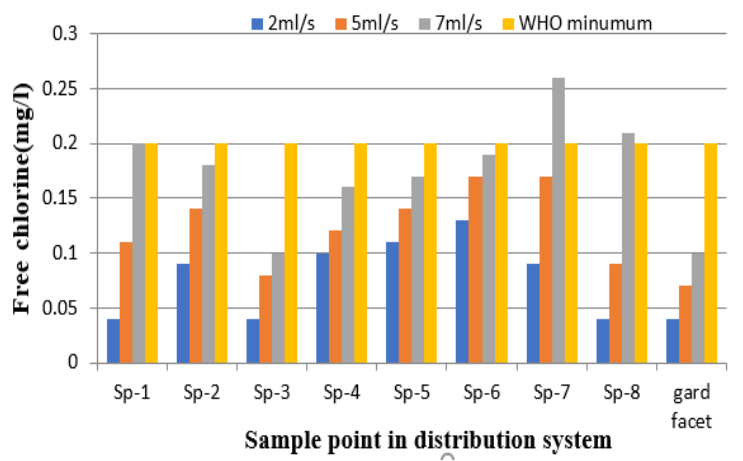

Fig. 3. Residual chlorine value with $1.5 \mathrm{~kg}$

From those sample points analysis residual chlorine results in the distribution system by adjusting flow rates into $2 \mathrm{ml} / \mathrm{s}, 5 \mathrm{ml} / \mathrm{s}$ and $7 \mathrm{ml} / \mathrm{s}$ the recorded values were; for $2 \mathrm{ml} / \mathrm{s}$ chlorine flow rates the residual chlorine was recorded $37.5 \%$ between the range of 0.1-0.2 $\mathrm{mg} / \mathrm{l}$ (Grabovich et al., 2001) and 
$62.5 \%$ was less than $0.1 \mathrm{mg} / \mathrm{l}$. For $5 \mathrm{ml} / \mathrm{s}$ chlorine flow rates the residual chlorine was recorded $75 \%$ which was between the range of 0.1 to $0.2 \mathrm{mg} / \mathrm{l}$ and $25 \%$ was less than $0.1 \mathrm{mg} / \mathrm{l}$ and also, for $7 \mathrm{ml} / \mathrm{s}$ chlorine flow rates the residual chlorine was recorded $37.5 \%$ between the range of 0.2-0.3 mg/l (Karikari \& Ampofo, 2013) and $62.5 \%$ was between the range of 0.1 to $0.2 \mathrm{mg} / \mathrm{l}$. The entire three alternatives except ( 7 $\mathrm{ml} / \mathrm{s} ; 37.5 \%)$ the other alternatives cannot find the minimum residual chlorine $(0.2 \mathrm{mg} / \mathrm{l})$ in the far dead end of town networks. Even in the centre of the town have not found the minimum required residual chlorine.

\subsection{Assessment of Disinfection Process with $2 \mathrm{~kg}$ Chorine}

Chlorine solution concentration form in mixing tank with the amount of $2 \mathrm{~kg} \mathrm{Ca}(\mathrm{OCl})_{2}$ was calculated as:

Dose concentration $=\frac{2000 \times 65 \%}{1000 l}=\frac{1300 \mathrm{mg}}{l}$

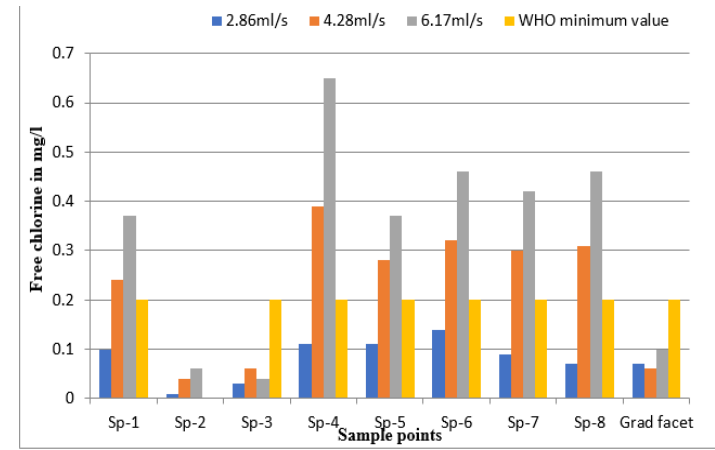

Fig. 3. Residual chlorine with $2 \mathrm{~kg}$ chlorine solution

The residual chlorine content in the distribution systems when applied $2 \mathrm{~kg} \mathrm{Ca}(\mathrm{OCl})_{2}$ chlorine dose solution with different flow rates of $2.86 \mathrm{ml} / \mathrm{s}$ in all samples were found below $0.14 \mathrm{mg} / \mathrm{l}$ as (Fig.4). However, within this amount of dose solution using $4.28 \mathrm{ml} / \mathrm{s}$ average flow rates residual chlorine occurred $25 \%$ less than $0.07 \mathrm{mg} / \mathrm{l}$ and the rest $75 \%$ were found between 0.2 to $0.5 \mathrm{mg} / \mathrm{l}$. Adjusting injection amount of chlorine solution with average value of $6.17 \mathrm{ml} / \mathrm{s}$ residual chlorine results have recorded $62.5 \%$ found between 0.2 to $0.5 \mathrm{mg} / \mathrm{l}$ and one sample was recorded $0.65 \mathrm{mg} / \mathrm{l}$, this value was above the maximum limits and also, $25 \%$ below 0.1 $\mathrm{mg} / \mathrm{l}$. When $2 \mathrm{~kg} \quad \mathrm{Ca} \quad(\mathrm{OCl})_{2}$ chlorine dose concentration flow rate amount increases do not address all the distribution system with recommended ranges of residual chlorine, rather maximum residual chlorine has been found $(0.65 \mathrm{mg} / \mathrm{l})$.

\subsection{Model calibration and validation 3.4.1. Model calibration}

The objective of the water quality model calibration is to minimize the difference between the field observed and model-simulated chlorine concentration values. For calibrations that was selected the most appropriated fitted of the trial results, which have overlay above correlation line within the value of observed and simulated results. So that, from trial option it was assessed with $2 \mathrm{~kg}$ chlorine dose by 4.28 and $6.17 \mathrm{ml} / \mathrm{s}$ chlorine solution flow rates observed residual chlorine result had recorded within the recommended values when compared to other option and it used for model calibration as observed data.

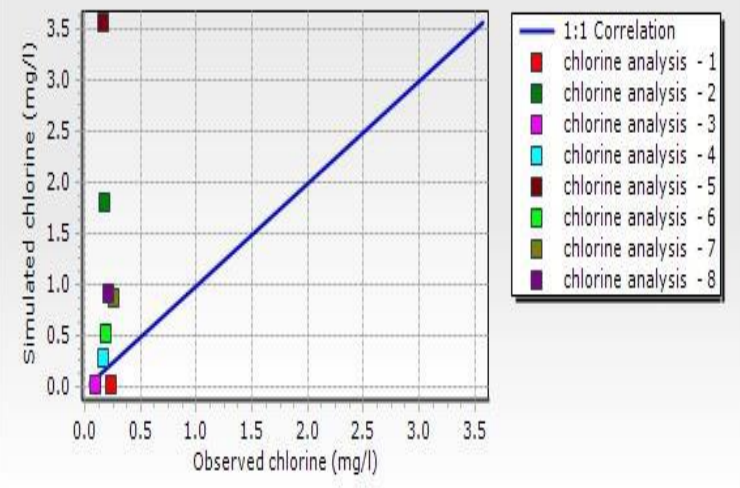

Fig. 4. Model calibration

The model calibrates with recommended scenarios for selected initial injection value $0.45 \mathrm{mg} / \mathrm{l}$ and two additional injection points with base chlorine dose $0.15 \mathrm{mg} / \mathrm{l}$ and $0.2 \mathrm{mg} / \mathrm{l}$ (Fig. 5). Because within short periods in all networks have residual chlorine concentration within standard limits $(0.2$ to $0.5 \mathrm{mg} / \mathrm{l})$. Model scenario one: initial chlorine dose $0.6 \mathrm{mg} / 1$

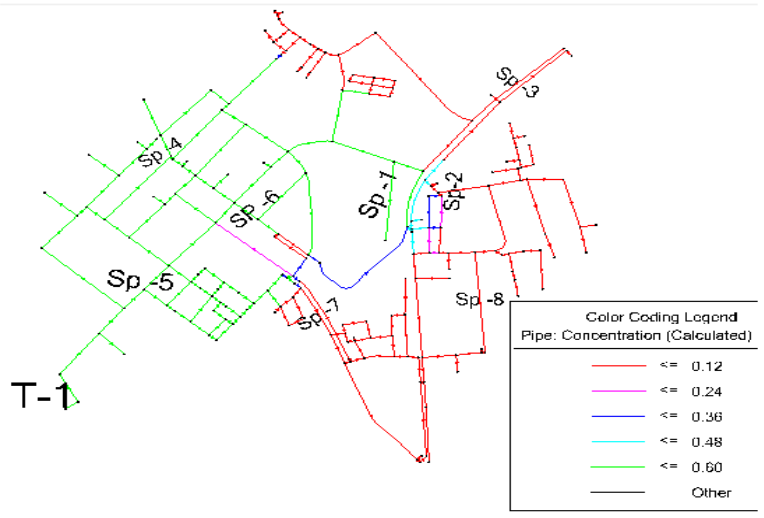

Fig. 5. Residual chlorine with $0.6 \mathrm{mg} / \mathrm{l}$ at after 18 hours 
The Chorine concentration amount in the most pipes nearest to the reservoir was found $0.6 \mathrm{mg} / \mathrm{l}$ and it was above the maximum limits of $0.5 \mathrm{mg} / \mathrm{l}$ (Fig. 6). The other pipes in the network were found $0.12 \mathrm{mg} / \mathrm{l}$, which was below the minimum limits $(0.2 \mathrm{mg} / \mathrm{l})$. To manage this scenario required.

Model scenario two: initial chlorine dose $0.5 \mathrm{mg} / \mathrm{l}$

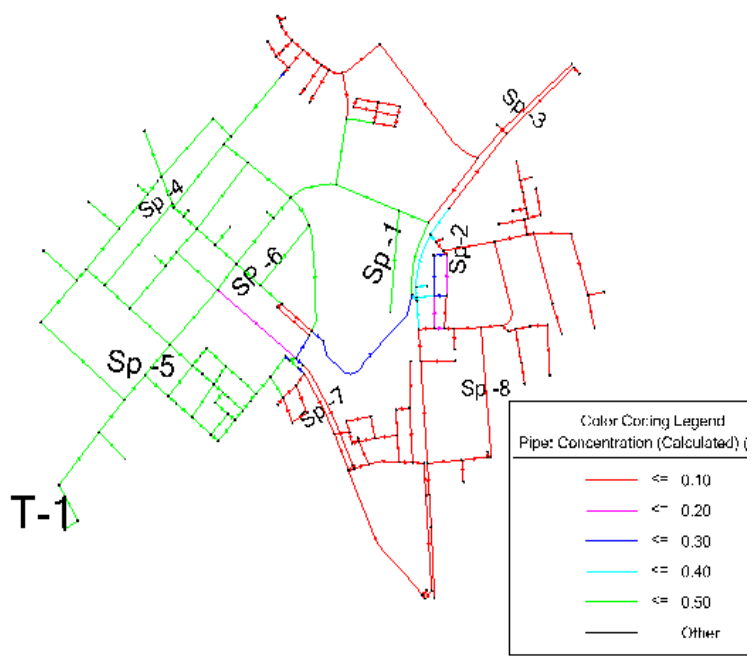

Fig. 6. Residual chlorine with $0.5 \mathrm{mg} / \mathrm{l}$ after 18 hours

In scenarios two shown in Fig. 7 was developed using initial chlorine concentration of $0.5 \mathrm{mg} / \mathrm{l}$, the values of free chlorine more than $50 \%$ results found within the range of $0.4-0.5 \mathrm{mg} / \mathrm{l}$. While the rest pipe networks have less than $50 \%$ that displayed between $0-0.1 \mathrm{mg} / \mathrm{l}$ of free chlorine. In this scenario, the values of the free chlorine model fluctuated between $0.08-0.5 \mathrm{mg} / 1$ at each sampling points. In this simulation of the existing situation indicated that the distribution of residual chlorine in the network is not adequate in most of the areas. The second scenario also could not solve the problem. For this reason, they are applying injection points to the distribution networks to get adequate minimum residual chlorine throughout the system.

\subsection{Assessment of injection points}

Injection points use to confirm the area where cannot get a minimum level of chlorine in the networks. To balance residual chlorine throughout the distribution system initial concentration of 0.45 $\mathrm{mg} / \mathrm{L}$ and an additional two chlorine injection points within 0.15 and $0.2 \mathrm{mg} / \mathrm{l}$ was applied. Injection base chlorine concentrations were installing near SP-7 at J-4 and SP-1at junction 55' respectively. Sample point seven selection criteria, during assessing existing situation were due to the existence of high total coliform.

Water CAD was used to evaluate free chlorine and to predict areas where, the residual chlorine concentration was lower than the minimum recommended value of $0.2 \mathrm{mg} / \mathrm{l}$ in the distribution network (Sila, 2019). As shown in Fig. 8, for each chlorine concentration, the final chlorine injection rates by the proposed model were lower than those obtained from field assessments. When the water quality responses of previous two scenarios are compared, it can be seen that both proposed models are not found the minimum chlorine residuals of 0.20 $\mathrm{mg} / \mathrm{l}$ for all the networks. On the other hand, maximum chlorine residual values obtained by the proposed model were greater than the one obtained nearest to service reservoir. However, these differences are not significant, and the maximum chlorine residuals were still in the range of permissible residual limits (N'garam et al., 2017). It was clearly seen that average residual values were in the range of $0.20-0.55 \mathrm{mg} / \mathrm{l}$ for all the networks, more uniform residual distributions are obtained especially, near injection points and surrounding areas.

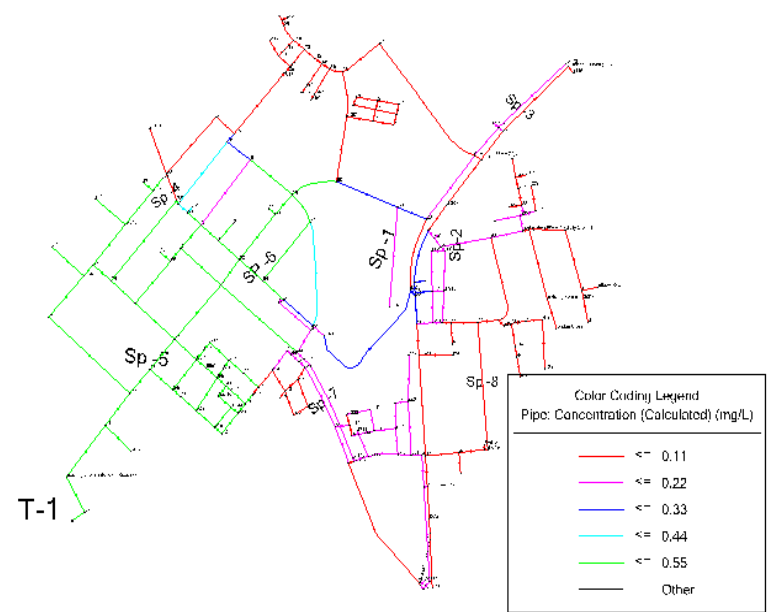

Fig. 7. Residual chlorine at 12 -hour $(0.45+0.15+0.2)$ $\mathrm{mg} / \mathrm{L}$

When the model was run, initial mean residual chlorine surrounding service reservoir has recorded $0.45 \mathrm{mg} / \mathrm{l}$. With this value most of the nodes and pipes in 12 hours' duration the result has displayed within the recommended values in including farthest to service reservoir (Fig. 8). When compare to the previous all model scenarios within short time (12 hours) the values of this scenario were the best adequate but, some existing end points have not got the minimum values of residual chlorine. To fit the most and appropriate chlorine dose in all the networks were using another option at 20-hour duration (Fig. 9). 


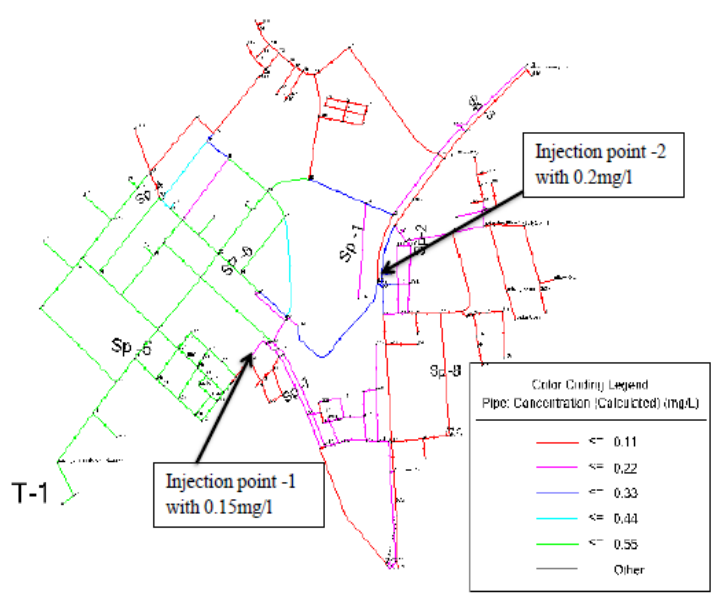

Fig. 8. Residual chlorine at 20-hour $(0.45+0.15+0.2)$ $\mathrm{mg} / \mathrm{L}$

In the third scenario, the values of free chlorine in most of the samples were found within the WHO \& ESA guideline $0.2-0.5 \mathrm{mg} / \mathrm{l}$. In this model scenario, the town water distribution networks have more than $90 \%$ part of the pipes and nodes have residual chlorine value within the range of $0.15-0.5 \mathrm{mg} / \mathrm{l}$ in all distribution networks while regarding sample points were founds between $0.2-0.5 \mathrm{mg} / \mathrm{l}$. So that, additional two chlorine injection points with initial concentration at service reservoir $0.45 \mathrm{mg} / \mathrm{l}$ and using 0.15 and $0.2 \mathrm{mg} / \mathrm{l}$ dose injection points respecting location it addresses all networks with recommended values at short time. Generally, additional chlorine injection points are essential for supply adequate all the networks because; reservoir chlorination was not overlying all the networks with short time and also not got the minimum recommended result at the dead-end of the pipes.

\subsection{Disinfection model scenarios evaluation}

The values of residual chlorine monitoring data on the water network through the day, which started from 12 hours to 18 hours for the three scenarios.

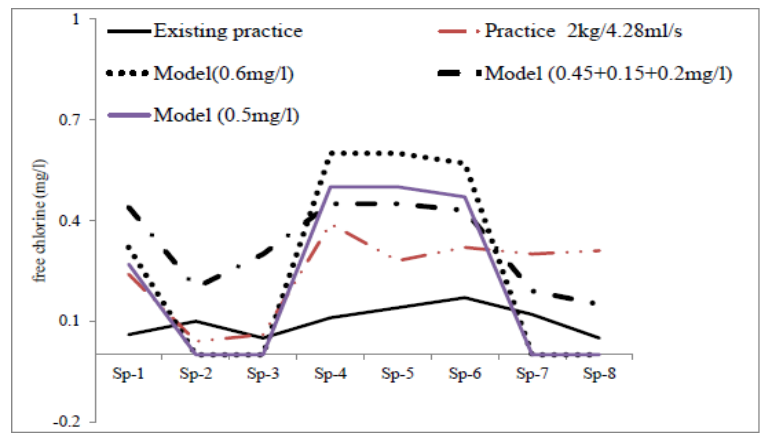

Fig. 9. Free chlorine value relations at 12 hours
When compared each scenario in 12 hours, the third one was most appropriated, and the results have displayed within a short period $75 \%$ of networks have residual chlorine within the range of 0.2-0.45 $\mathrm{mg} / \mathrm{l}$. The results of these scenarios are within a range of WHO standards. So, the third model scenario was the best economical methods and recommended for the office.

\subsection{Model validations}

For validations, we selected the most appropriated fitted of the trial results have recorded, and this overlay within a short time. These trials selected depends on the result have which related to the standard limits. So that, from trial practice we assessed with $1.5 \mathrm{~kg}$ and $2 \mathrm{~kg}$ solution by $7 \mathrm{ml} / \mathrm{s}$ and $4.28 \mathrm{ml} / \mathrm{s}$ dose flow rates result have recorded within the range of $0.1-0.5 \mathrm{mg} / \mathrm{l}$ values when compared to other results trial practice, and is used for model calibration as observed data. The model calibrates with recommended scenarios selected $(0.45+0.15+0.2$ $\mathrm{mg} / \mathrm{l}$ ) because, within short periods in all networks have residual chlorine concentration within standard limits.

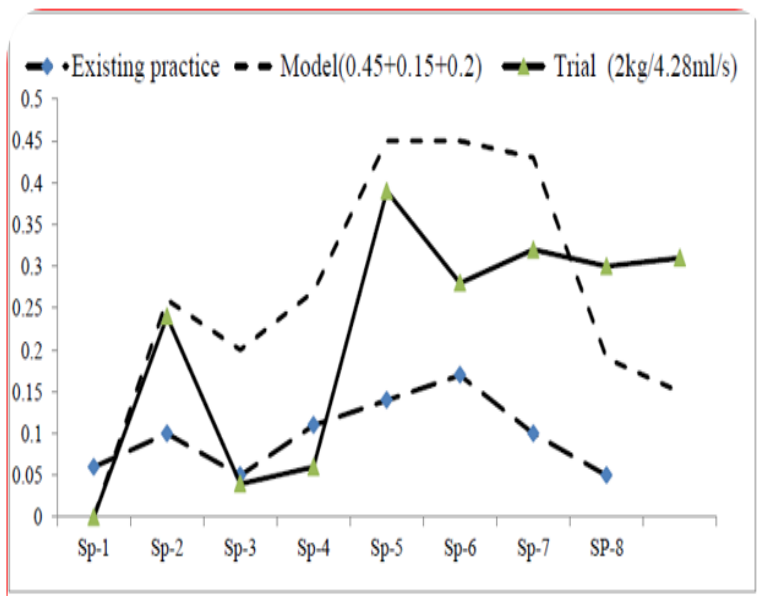

Fig. 10. Mean residual chlorine validation at sampling points

Existing practice and chlorine dose solution $2 \mathrm{~kg} / \mathrm{l}$ by $4.28 \mathrm{ml} / \mathrm{s}$ dose flow rates there were statistically significant differences $(\mathrm{p}=0.006$, P-value $<0.05)$. The second option, existing practice and scenario model $(0.45+0.15+0.2 \mathrm{mg} / \mathrm{l})$ also there were statistically significant differences $(\mathrm{p}=0.002$, Pvalue < 0.05) between the existing practice and on this new scenario model-free chlorine value within 18 hours, at all sample points the mean value was within 0.15-0.5 mg/l. Even, at this scenario for sample points (3 and 8) respectively which were far from service reservoir have a dead-end, low pressure, low 
velocity and high-water age which have the means value was between $0.15-0.5 \mathrm{mg} / \mathrm{l}$. So, the second option calibration validation was which indicate the best-fit scenario free chlorine value in the networks compared to other options. It is clear that the amount of free chlorine measured sample points in the third scenario was the highest value when compared with the other the scenarios and should be considered to get safe water from microbial contamination.

\section{CONCLUSIONS}

Dangila's town residual chlorine concentration in the entire distribution networks under existing conditions has below $0.17 \mathrm{mg} / \mathrm{l}$. Chlorination level current practice $100 \%$ of collected samples does not comply with WHO and ESA minimum limit (0.2 $\mathrm{mg} / \mathrm{l})$. The bacteriological assessment confirmed that no faecal coliforms exist; however, the total coliform has happened with the maximum number of 5 colonies per $100 \mathrm{ml}$ sample. By using $1.5 \mathrm{~kg}$ chlorine dose at $7 \mathrm{ml} / \mathrm{s}$ solution flow rates from the collected samples $77.78 \%$ has found between $0.1-0.2 \mathrm{mg} / \mathrm{l}$ and $22.22 \%$ above $0.2 \mathrm{mg} / \mathrm{l}$. In the same way, $2 \mathrm{~kg} / 6.17$ $\mathrm{ml} / \mathrm{s}$ from collected samples of $55.56 \%$ has been found between $0.2-0.5 \mathrm{mg} / \mathrm{l}$. Although, most of the results from the analysis were within the recommended values some of the results indicate above the maximum limits and some of them were below the minimum limits $(11.11 \%$ of the samples resulted in $0.65 \mathrm{mg} / \mathrm{l}$ and $33.34 \%$ results below 0.1 $\mathrm{mg} / \mathrm{l})$. So that, to balance residual chlorine use $2 \mathrm{~kg}$ dose by $4.28 \mathrm{ml} / \mathrm{s}$ flow rates $75 \%$ of the distribution systems have within the range of $0.2-0.5 \mathrm{mg} / \mathrm{l}$ and the rest $25 \%$ was less than $0.2 \mathrm{mg} / \mathrm{l}$. The physicochemical characteristics of water quality analysis revealed that all parameters except $\mathrm{pH}$ results were within the recommended value. Nevertheless, the value of $\mathrm{pH}$ has found between 8.68-9.1 ranges.

When age increases throughout the network, there is a higher consumption of chlorine. Due to this reason, it may be no existing residual chlorine in the network's pipe. Water age is the most crucial factor for deteriorating water quality and reduction of chlorine in the water pipes. Using $2 \mathrm{~kg}$ chlorine dose, residual chlorine model was developed by initial concentration within three different scenarios. The scenarios II and I were formed with initial concentrations of $0.6 \mathrm{mg} / \mathrm{l}$ and $0.5 \mathrm{mg} / \mathrm{l}$, respectively. The scenario I was near to the service reservoir, which was displayed above $0.5 \mathrm{mg} / \mathrm{l}$. Among all results, Scenario II have displayed below $0.5 \mathrm{mg} / \mathrm{l}$. Two injection points within 0.15 and $0.2 \mathrm{mg} / \mathrm{l}$ of initial chlorine dose concentration were installed in the third scenario to confirm area where the minimum residual chlorine level cannot be obtained. In this case, all distribution networks have residual chlorine with acceptable standard limits. Therefore, the third model scenario was the best mechanism to alleviate the situation to minimize the shortage of chlorine.

\section{ACKNOWLEDGEMENT}

We would like to express our appreciation to the staff of water supply and sanitary engineering department Bahir Dar university, Dangila Water and Sewerage office and Dangila Woreda water development office that helped us to get all the necessary data. We also, grateful to our family and all our friends for their financial, material and moral support.

\section{REFERENCES}

[1] Berhanu, A. \& Hailu, D. (2015). Bacteriological and physicochemical quality of drinking water sources and household water handling practice among rural communities of Bona District, Sidama zone, Zouthern, Ethiopia. Science Journal of Public Health, 3(5), 782.

[2] Bolton, J. R. \& Cotton, C. A. (2011). The ultraviolet disinfection handbook: American Water Works Association.

[3] Bruins, H. J. (2000). Proactive contingency planning vis-à-vis declining water security in the 21 st century. Journal of contingencies and crisis management, 8(2), 63-72.

[4] Clark, R. M., Rossman, L. A. \& Wymer, L. J. (1995). Modeling distribution system water quality: Regulatory implications. Journal of water resources planning and management, 121(6), 423-428.

[5] Goyal, R. V. \& Patel, H. (2015). Analysis of residual chlorine in simple drinking water distribution system with intermittent water supply. Applied Water Science, 5(3), 311-319.

[6] Grabovich, M. Y., Patritskaya, V. Y., Muntyan, M. S. \& Dubinina, G. A. (2001). Lithoautotrophic growth of the freshwater strain Beggiatoa D-402 and energy conservation in a homogeneous culture under microoxic conditions. FEMS microbiology letters, 204(2), 341-345.

[7] Hu, C.-M. J., Aryal, S. \& Zhang, L. (2010). Nanoparticle-assisted combination therapies for 
effective cancer treatment. Therapeutic delivery, 1(2), 323-334.

[8] Kabir, G., Tesfamariam, S., Francisque, A. \& Sadiq, R. (2015). Evaluating risk of water mains failure using a Bayesian belief network model. European Journal of Operational Research, 240(1), 220-234.

[9] Karikari, A. \& Ampofo, J. (2013). Chlorine treatment effectiveness and physico-chemical and bacteriological characteristics of treated water supplies in distribution networks of AccraTema Metropolis, Ghana. Applied Water Science, 3(2), 535-543.

[10] Males, R. M., Grayman, W. M. \& Clark, R. M. (1988). Modeling water quality in distribution systems. Journal of Water Resources Planning and Management, 114(2), 197-209.

[11] Mekonnen, D. K. (2015). The effect of distribution systems on household drinking water quality in Addis Ababa, Ethiopia, and Christchurch, New Zealand.

[12] Myre, E. \& Shaw, R. (2006). The turbidity tube: simple and accurate measurement of turbidity in the field. Michigan Technological University.

[13] N'garam Nambatingar, Y. C., Merle, A., Mahamat, T. N. \& Lanteri, P. (2017). Heavy metal pollution of Chari river water during the crossing of N'Djamena (Chad). Toxics, 5(4).

[14] Niazi, S., Kalbasi, M. \& Bahramian, A. (2017). Full scale experimental study of an ozonation reactor: Effects of seasonal water characteristics and operating conditions on total organic carbon removal, aldehydes and ketones formation as well as disinfection efficiency. Journal of environmental chemical engineering, 5(2), 15361547.

[15] Ododo, M. M., Physico-chemicals and Heavy Metals Analysis of Drinking Water of Aksum University, Tigrai region, Ethiopia.
[16] Post, G., Atherholt, T. \& Cohn, P. (2011). Water quality and treatment: a handbook on drinking water. Health and aesthetic aspects of drinking water, 6th edn. McGraw-Hill, New York, 2.1-2.100.

[17] Sila, O. N. A. (2019). Physico-chemical and bacteriological quality of water sources in rural settings, a case study of Kenya, Africa. Scientific African, 2, e00018.

[18] Sorlini, S., Palazzini, D., Sieliechi, J. \& Ngassoum, M. (2013). Assessment of physicalchemical drinking water quality in the Logone Valley (Chad-Cameroon). Sustainability, 5(7), 3060-3076.

[19] Soyupak, S., Kilic, H., Karadirek, I. \& Muhammetoglu, H. (2011). On the usage of artificial neural networks in chlorine control applications for water distribution networks with high quality water. Journal of Water Supply: Research and Technology-Aqua, 60(1), 51-60.

[20] Temgoua, E. (2011). Chemical and bacteriological analysis of drinking water from alternative sources in the Dschang municipality, Cameroon. Journal of Environmental Protection, 2(5), 620 .

[21] Ustad, I. (2018). Bacteriological analyses of water used for drinking from borehole of Omerga region, Osmanabad district in Maharashtra.

[22] Yee, L. F., Abdullah, M. P., Ata, S. \& Ishak, B. (2006). Dissolved organic matter and its impact on the chlorine demand of treated water. Malaysian Journal of Analytical Sciences, 10(2), 243-250.

[23] Zaki, S., Elkady, M., Farag, S. \& Abd-ElHaleem, D. (2012). Determination of the effective origin source for nanosilver particles produced by Escherichia coli strain S78 and its application as antimicrobial agent. Materials Research Bulletin, 47(12), 4286-4290. 